\title{
A Study on Measures to Promote Rural Community Empowerment Project for Residents in Jinja, Uganda: Focused on On-Site Investigation on the Feasibility of Creating a Tourism Agriculture Complex
}

\author{
Yong Jo Jung* \\ Assistant Professor, Department of Environmental Landscape Architecture, Sangmyung University, Cheonan 31066, Korea
}

\section{ABSTRACT}

The purpose of this research is to strengthen rural community empowerment by creating a tourism farm as a plan to reduce relative poverty and to improve the quality of life by creating jobs and increasing the income of local residents in underdeveloped countries. To do so, literature review, stakeholder interviews, on-site investigations, focus-group interviews, a project meeting for residents and a questionnaire survey were performed and analyzed and the results were as follows.

First, Uganda has the potential to increase agricultural production based on its warm climate, fertile land and abundant natural resources. The quality of life of local residents is expected to be improved by realizing high-added values through the convergence of the conventional existing agricultural industry and other industries if the agricultural technology is properly transferred based on abundant labor force and low labor expenses. Opportunities for the success of the project can be spread to other rural villages across the country. Second, since local residents are now cultivating sugar cane, cassava, matoke, banana, coffee and so on as a farm owner, tourism agriculture with high-added values can be promoted by vitalizing communities based on farming technology to be transferred and a cooperative farm. It is also necessary to implement a rural community empowerment project to do so. Third, the university that is the cooperative partner of the project is positively considering to train experts by establishing a community development department, and, if necessary, a technical training center to educate the general public, which is expected to create synergic effects through the convergence of education, agriculture and tourism.

Keywords: community vitalization, improved quality of life, rural development

\section{Introduction}

Rural areas are now experiencing various changes and difficulties due to changing internal and external situations and social structures. In order to address problems observed in rural areas such as social problems caused by changes in population structure and environments for production and economic difficulties, it is essential to vitalize communities, establish a foundation for income sources and strengthen competence of residents through community empowerment. The Korean government has also expanded projects related to community development such as community building in order to increase the income and basic living standards of residents in rural areas, maintain population and promote the specialized development of individual communities (Kim et al., 2017; Ministry of Agriculture, Food and Rural Affairs, 2014).

Community development aims to ensure residents identi-

This study was conducted based on the report of 2018 KOICA-KAIDEC Incubating Program for Academy.

Received: November 29, 2019, Revised: December 10, 2019, Accepted: January 3, 2020

First author: Yong Jo Jung, smilejung@smu.ac.kr, (1) https://orcid.org/0000-0003-1518-2161

*Corresponding author: Yong Jo Jung, smilejung@smu.ac.kr, (i) https://orcid.org/0000-0003-1518-2161 
fy problems that they want to address, set goals and solve problems by promoting their autonomous competence, engagement, self-determination, cooperation and self-reliance, democratic procedures, education, group dynamics, empowerment and indigenous leadership (Choi and Lee, 2015; Kim et al., 2017).

Community development projects in Korea were initiated in the late 1950s for the purpose of the social and economic stability of Korean society, and since then they have evolved into those in the form of rural extension (Han, 2008; Kim et al., 2017). Since 1957, domestic rural extension projects have been led by the government as they were influenced by the United States, and different forms of community development have been tried in postwar Korea (Jung, 1997; Kim et al., 2017). Today, rural community empowerment projects are executed to restore underdeveloped villages in rural areas.

Korea has helped projects for community development and empowerment in developing countries through overseas aid projects, and they mainly focus on development projects that converge different areas such as economy, infrastructure, education and health care (Lee, 2018). In developing countries, over $70 \%$ of their population live in rural areas and a combination of shortages in various areas including economy, society and environment have been observed in these areas. For this reason, the international community has made considerable efforts for comprehensive development to achieve its goals such as eradication of poverty and balanced growth around the world (Heo and Hong, 2017; Lee, 2018).

Uganda, selected as a target country in this study, has abundant water resources as $17 \%$ of its territory is covered by lakes and rivers. The total area of arable lands is 8.28 million ha (4.6 times larger than that of arable lands in Korea), one third of its territory, and with its fertile soil and abundant natural resources. Uganda is capable of producing a sufficient amount of agricultural products that can support double the population of East Africa. Approximately $73 \%$ of the population of Uganda is engaged in agriculture and the industry contributes to $54 \%$ of the total amount of export and $25.3 \%$ of GDP, playing a key role in the economic growth and poverty reduction of Uganda. However, poor agricultural production infrastructure such as seed, fertilizer, mechanization and irrigation technology and vulnerability of policies and institutional support have been pointed out as key obstacles to the development of rural areas. For this reason, the Ugandan government set as a goal increasing the income of rural areas through agricultural development and strengthening national competitiveness through the establishment of the value chain of agriculture by 2020 (Korea International Cooperation Agency and Korea Association of International Development and Cooperation [KOICA and KAIDEC], 2019). It is essential at this juncture to improve access to new rural community empowerment projects for rural areas to create high values by converging the conventional agricultural industry with other industries.

There were several studies conducted on rural community empowerment. Ji (2006) studied ways to empower local communities and pointed out that empowerment can be achieved by securing autonomy through the restoration and promotion of the rights of community members, developing and expanding social and economic capital, organizing local communities and expanding human capital. Jung et al. (2015) analyzed the factors that affect the empowerment of strong small farms and reported that the rate of change in competence of farms that wrote both management planning and execution reports was higher than the rate of those that wrote a management planning report only, and that the competence and income of farmers can be increased by promoting the effectiveness of projects or writing a management improvement note or participating in education. Oh and Kim (2015) examined ways to vitalize the center of rural areas by promoting the engagement of residents and reported that planning the vitalization of the center of rural areas through residents' autonomous efforts based on their regional characteristics can lead to the active and successful growth of the areas. Kwon et al. (2015) studied education for the empowerment of residents by the type of rural villages focusing on the creation of differentiated villages and reported that education for empowerment increased the ability of residents to recognize the characteristics of their villages, which highlighted the importance of empowerment education and in particular the necessity of empowerment education programs for women. Kwon et al. (2008) examined trends in community empowerment projects and 
empowerment project models and reported that community empowerment can deliver visible outcomes only when three factors - residents' intention to innovate, the active attitudes of public officials and heads of local governments and the decentralization and support of the central government for localized projects - are met. Kim et al. (2017) examined the learning phases and empowerment of residents for rural community development focusing on independent rural community creation projects and pointed out that community development requires the engagement of residents, which is a very important element for the success of community development. They also suggested to encourage residents to establish development plans on their own through motivation.

In developing countries, over $70 \%$ of the poor population live in rural areas and a combination of shortages in various areas including economy, society and environment is observed in the areas. For this reason, it is essential to comprehensively develop the areas to achieve goals such as eradication of poverty and balanced growth around the world. The Ugandan government, a target country of this study, announced its national development vision (Vision 2040) - transforming from small farmers-based society to modern and prosperous society within 30 years - and suggested as a goal strengthening national competitiveness by increasing the income of rural areas through agricultural development and establishing an effective value chain for agriculture. Against this backdrop, this study aimed to suggest measures to improve the quality of life of residents in Jinja, Uganda. One of them is to focus on the value chain of crops produced in each area with the model that advances agriculture into the primary + secondary industry (developing various products by building processing factories in rural areas instead of supplying raw materials only) to the secondary + tertiary industry (operating shops to sell the products that are directly produced in the areas) and to the 6th industry (primary + secondary + tertiary industry, turning the entire processes including cultivation, harvesting, processing, sales and experience into tourism products). There are other measures such as connecting with tourism agriculture by discovering factors that strengthen the autogenous ability of residents, providing quality jobs by improving agricultural production technology and vitalizing communities, and increasing the income of residents in rural areas.
As discussed above, this study was initiated with the understanding of the fact that empowering local communities is the basic starting point for improving the life of residents and transforming communities into healthy communities where residents can solve local problems on their own. Community empowerment projects need to be settled down based on the understanding of the current situations of rural areas such as community engagement and income conditions.

\section{Research Methods}

\section{Selection of target site and research scope}

Jinja, a city in Uganda, has beautiful natural landscapes as the origin of the Nile River and is located on the shores of Lake Victoria. As tourists around the world come to see attractive places in the city, the growth of its local economy has been driven by tourism and service industries. Although the foreign capital has flown into the industries and has temporarily created jobs, villages near Jinja have continued to experience problems such as population vacuum, a decrease in the population engaged in agriculture and a shortage of infrastructure. As people move to the center of the region to find jobs, people no longer pay attention to the major industries of Jinja such as agriculture, manufacturing and processing of agricultural products, loosing the industrial potential of the city (KOICA and KAIDEC, 2019). For this reason, the necessity of rural community empowerment projects has increased to improve the autogenous ability of residents in Jinja to develop the potential of the value chain based on agriculture (primary industry) and to connect Uganda's unique local cultures with the tourism and service industries in the center of the region. In line with that, Jinja was selected as a target site (Fig. 1) and the scope of this study was set as follows:

First, the climate, soil and natural landscapes of Jinja, Uganda and the status of crop cultivation were surveyed to analyze the feasibility of creating a tourism-agriculture complex.

Second, since a large-sized state-owned or publicly-owned land is needed to create a tourism-agriculture complex, on-site investigations were conducted to examine the avail- 


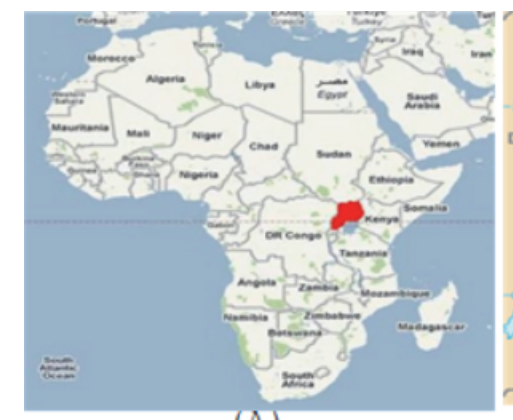

(A)

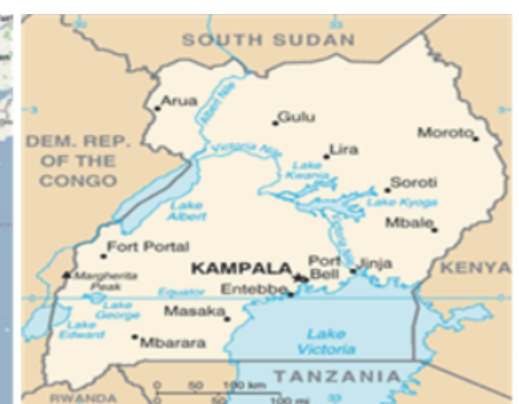

(B)

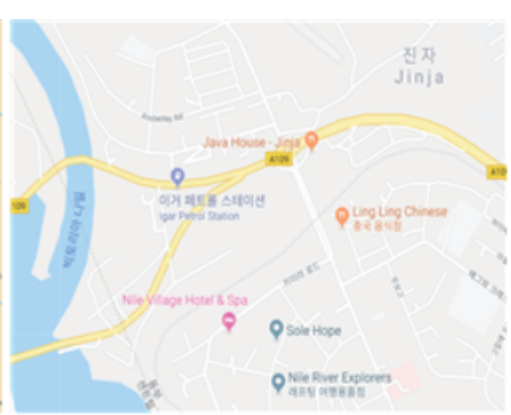

(C)

Fig. 1. Google map of Uganda in east-central Africa (A), location of Jinja in southern Uganda (B) and central region of Jinja (C).

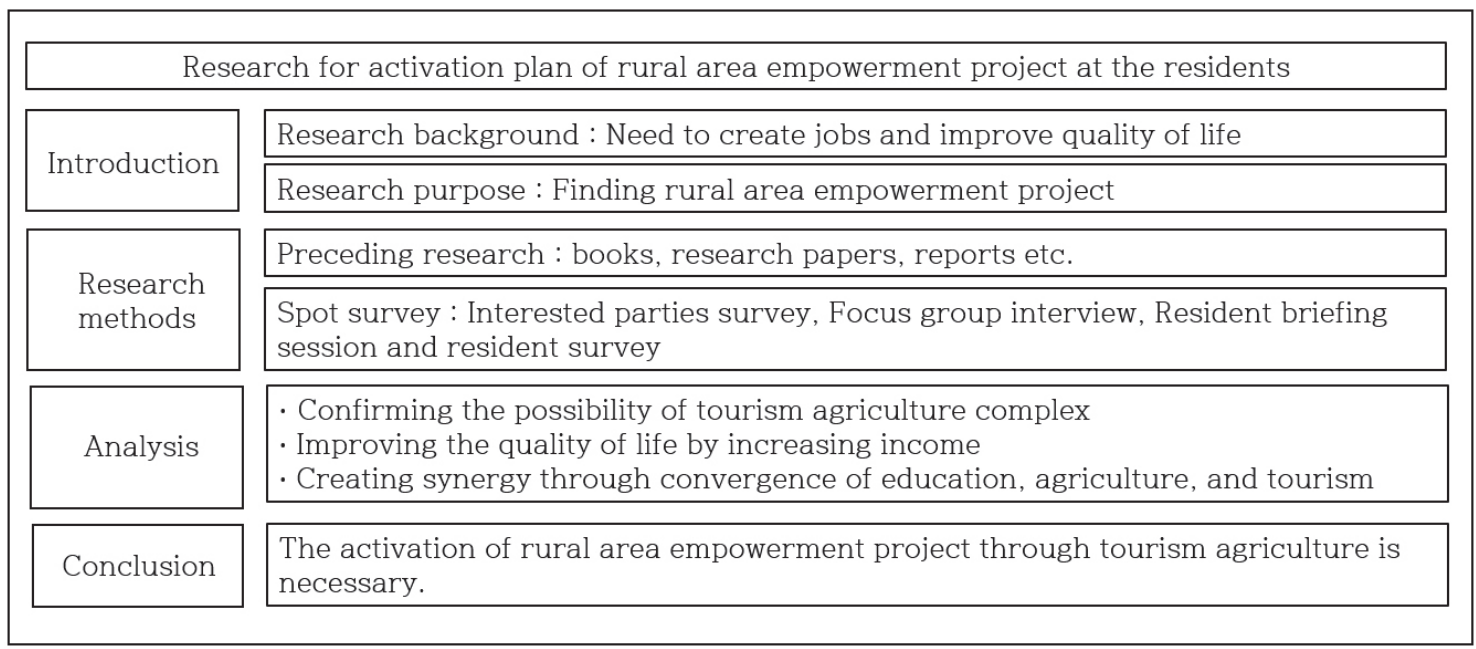

Fig. 2. The contents of the study.

ability of free support from the central and local governments and the feasibility of creating a tourism-agriculture complex on the land.

Third, the status of crops cultivated on site and cash crops that can drive the growth of tourism agriculture and fair tourism were surveyed and analyzed through on-site investigations.

Fourth, to examine the possibility of converging education, agriculture and tourism, surveys were conducted on the status of education, agricultural technology and the tourism types of foreign tourists who visited the site.

Fifth, physical and human infrastructure and support systems for creating a tourism-agriculture complex were surveyed and analyzed.

\section{Methods}

The purpose of this study is to develop a rural commun- ity empowerment project tailored for local conditions in order to reduce relative poverty that residents feel, create jobs and improve their quality of life, and different methods such as literature review, stakeholder interview, on-site investigation, focus-group interview, presentation for residents and questionnaire survey were adopted as follows (Fig. 2).

First, to analyze the status of the target site, related documents and earlier studies were reviewed, mainly focusing on books, theses and reports.

Second, interviews were conducted on local residents, the recipients of the central and local governments, relevant departments within the target site (RDA KOPIA Center, NILE CORPERATION), experts on the target site (public officials in Jinja, Uganda and East African University) and persons in charge in the recipient country (experts on agricultural development, tourism and trade in Uganda). 
Third, on-site investigations were conducted from January 9 to 15,2019 for 7 days by visiting Jinja to survey and analyze its climate, soil, crop cultivation, tourism types and educational conditions and the availability of support for educational cooperation from local residents.

Fourth, focus-group interviews were conducted on persons in charge in the central and local governments in Uganda to survey and analyze their interest in the project for cultivating high value-added cash crops and processing and marketing them as a strategy to transform poor farmers in Uganda into rich farmers and their intention to provide human resources, administrative services and the land needed for the project.

Fifth, a presentation for residents was held, targeting 151 residents who live in Flow Village (total population: 69) and Sabati Village (total population 82) 10 minutes away from the downtown of Jinja by car, and a total of 122 residents $(80 \%)$ participated in the presentation and a questionnaire survey was conducted on them. A total of 122 questionnaires were distributed and 111 answer sheets (excluding 11 sheets with unclear answers) were used as raw data. Using the data, factors that affect the life of residents in rural areas under five themes were analyzed using a multiple regression analysis. In addition, to understand residents' perception on this project, a presentation was also held for residents. The questionnaire used in the survey was largely composed of 13 questions to survey information such as basic information on respondents, allocation and productivity of agricultural resources, drinking water, housing and living environment, engagement in village committees, income, debt, disease, intention to participate in cooperative farms, intention to participate in opportunities to learn agricultural technology, measures to improve agricultural income and suggestions and elements required to vitalize local communities.

\section{Results and Discussion}

\section{Contents and analysis of stakeholder interview}

A stakeholder means an individual or group who affects a project or is affected by a project directly or indirectly and positively or negatively. This study aimed to analyze the characteristics of stakeholders, either individuals or groups, and relationships between them in order to improve the feasibility of project planning and identify recipient groups of the project. In this study, stakeholders include project recipients, relevant departments in the target site, KOICA's Korea office and the Korean embassy, RDA KOPIA Center, experts on the target site, and officials in charge in the recipient country, and they were surveyed to collect the following information: living environment, income, benefits, technological consultation for farmers, understanding of the project, intention to participate in the project, information on agricultural technology related to the project in Jinja, Uganda, agricultural development plans for Jinja, understanding and preference of new crops, understanding of expansion of the project and its merits and demerits. The results of the analysis were as follows.

First, about 300,000 foreign tourists visit Jinja every year to enjoy activities such as rafting, sightseeing and fishing in Lake Victoria and touring safari. There is a school specialized in tourism that provides education for those who want to be engaged in the tourism industry as hotel workers, tourist guides, hotel cooks, etc., and many of the graduates of the school are working in the tourism industry. The local government in Jinja wants to specialize tourism agriculture, but lack of contents for foreign tourists has been an obstacle to the vitalization of tourism businesses. Combined with the attractive elements of Lake Victoria and the origin of the Nile River, the efforts are expected to create significant synergic effects. The tourism agriculture cases suggested in this study including Tomita Farm in Hokkaido, Japan, L'Occitane in France, and Bongpyeong Heb Land and Gochang Green Barley Farm in Korea have been recognized by residents not only as a tourism business but also as an important business that can create secondary and tertiary industries. The Jinja government is very optimistic about the project in cooperation of the Ugandan president and is expected to spare no support for the success of the project. The Jinja government expressed its intention to invest, if necessary, even physical resources (a land for a tourism farm and administrative human resources). The land that the Jinja government can provide to create the farm is sized about $165,000 \mathrm{~m}^{2}$ and is easily 
accessible as it is located about 10 minutes away from the downtown of the city and the center of tourism. The land is owned by the Jinja government and gives dynamic landscapes with hills. Water can be smoothly supplied and there are abundant human resources such as young workers and female workers, which makes it suitable as a candidate for creating farms.

Second, the KOICA Korea office, the Korean Embassy and KOPIA (RDA Korean office) also confirmed that food and agriculture businesses lead the economy of Uganda, and farms mostly cultivate cash crops such as sugar cane, cassava, matoke and coffee. There are only few rice farms in Uganda unlike Korea. People's awareness of tourism agriculture is very low, but its favorable natural conditions such as warm climate and fertile soil, combined with its tourism resources, are expected to provide a good opportunity to create jobs and eradicate poverty. As Uganda needs a successful model for sustainable rural development projects, they expressed their positive intention to spread the movement.

Third, public officials in Jinja and leaders of East African University (principal and board members) were interviewed to survey the status of educational infrastructure in Jinja. There is no department in college that produces experts on rural development, but the department of construction engineering has provided project-type classes on theme spaces or community development. The key to rural development is to provide basic education on cultivation technology and agricultural machinery repairing techniques, and other skills such as cooperative spirit within the area, technical education, infrastructure and machinery repairing. In line with that, this study presented a blueprint for nurturing experts who can continuously work in the field by creating a rural development department and educating them on Korea's advanced technology (Fig. 3).

\section{Contents and analysis of on-site investigations}

On-site investigations focused on information required for community empowerment such as the possibility of cultivating cash crops excluding agricultural products for foods, the feasibility of developing farm touring programs connected with agricultural tourism, the possibility of processing cash crops to secondary or tertiary products and advancing them into a sixth industry, physical infrastructure and human resources required to develop rural areas, the quality of life of rural residents in the target site, types of residence and education. The results of the analysis were as follows.

First, the area of farms near Jinja is sized between 5 and 20 ha, and the most serious difficulty in cultivating crops is a shortage of agricultural machinery repairing techniques, which makes it difficult to mechanize farms and handle the vast land. For this reason, those farms have been cultivating key products only. Abundant human resources are available anytime, and the average monthly income is about 50,000-60,000 won. Since natural conditions in Uganda such as climate and soil are favorable for the project, once agricultural technology is successfully transferred to farmers, it will be possible to produce and process sugar cane, cassava and other crops in vast lands with abundant human resources, which is expected to brighten the future of agriculture and promote the tourism agriculture industry in Uganda.

Second, most of the tourism services (hotels, resorts) in Jinja are invested by Indian companies and the area of the

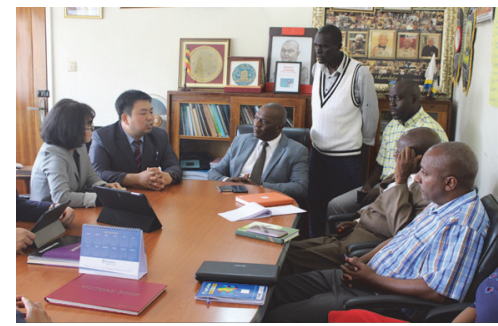

(A)

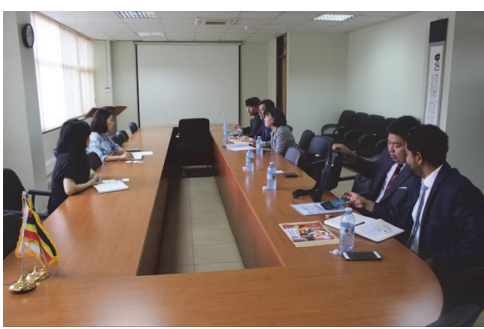

(B)

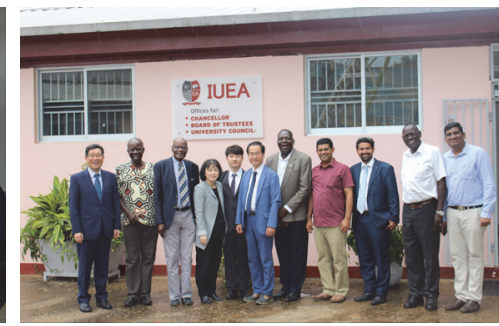

(C)

Fig. 3. Stakeholder Meetings: meeting with Jinja mayor (A), KOICA Korea office meeting (B), and meeting with the president of East African University (C). 
facilities is about 20 ha. Luxurious reports were built along the shoreline of Lake Victoria. The annual number of guests is $40,000-50,000$, and about $80 \%$ of them are foreign tourists, mostly family tourists. Hotels have developed and operated various programs for tourists such as festivals, horse riding and trails along the shoreline of the lake. The landscapes of areas near the hotels are cleanly and regularly kept by managers.

Third, farmers in Uganda and Jinja cultivate sugar cane, cassava, matoke, coffee and banana, and only few farms cultivate and export rice. The area of farms is huge, but the income is very low due to lack of agricultural technology. The soil in Uganda is fertile, which is suitable for cultivating any crop, and thanks to its constant climate $\left(17-25{ }^{\circ} \mathrm{C}\right)$ triple cropping is also possible for a year. Due to lack of processing technology, most of the agricultural products produced in the area are mostly directly distributed or exported without storing or processing. Since the agricultural industry of Uganda mostly focuses on producing agricultural products for foods and a few cash crops, high value-added tourism agriculture businesses can be promoted by developing a new model like the cases of Japan, France and Korea and utilizing its abundant human resources and favorable environments.
Fourth, East African University has its first campus in Kampala, the capital of Uganda, and the second campus in Jinja, Uganda, which makes it a good partner as a specialized educational institution. It is also selected as an excellent university in Africa and is suitable as a higher education institution for nurturing experts. East African University said that if this project is adopted, it will create a regional development department to produce talents needed for the project, and, if necessary, establish a technical training center for general people in order to introduce and learn Korea's advanced agricultural technology (Fig. 4).

\section{Contents and analysis of project meetings for residents and survey on residents}

A project meeting for residents and a survey were conducted on January 15, 2019 (Fig. 5) with the aims of contributing to Uganda's national development vision (Vision 2040) - transforming from small farmers-based society to modern and prosperous society within 30 years - and improving people's quality of life through rural community empowerment based on the national development plan. Their results were as follows (Table 1).

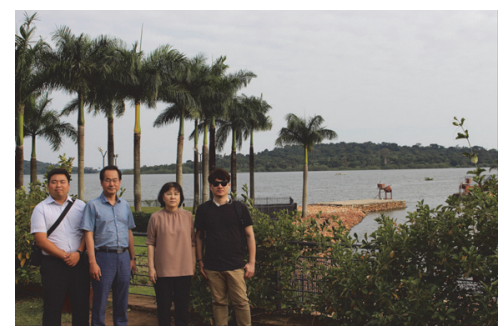

(A)

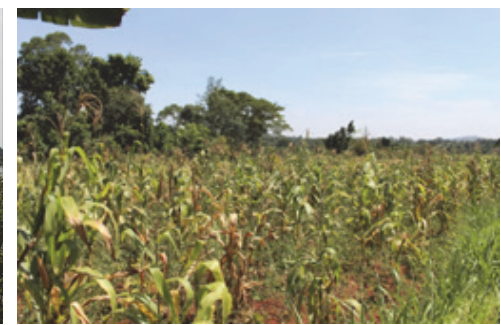

(B)

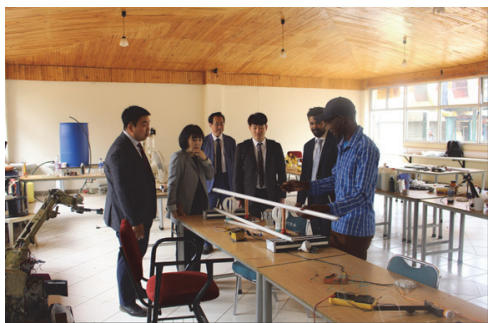

(C)

Fig. 4. Field survey at Lake Victoria (A), a sugar cane farm (B), and a science lab in East African University (C).

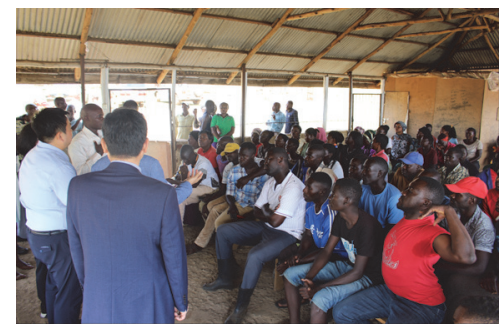

(A)

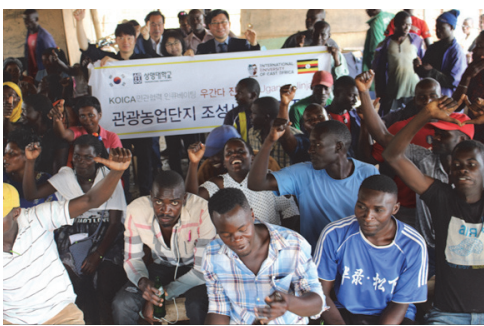

(B)

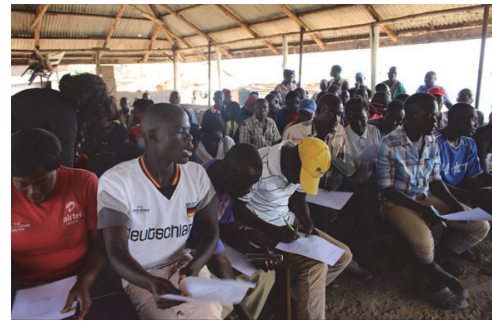

(C)

Fig. 5. A project brief at residents meeting ( $A$ and $B$ ) and conducting a survey on residents (C). 
Table 1. Survey contents

\begin{tabular}{|c|c|c|c|c|}
\hline \multicolumn{3}{|c|}{ Classification } & \multirow{2}{*}{$\frac{\text { Frequency }}{50}$} & \multirow{2}{*}{$\frac{\text { Percent }(\%)}{45}$} \\
\hline \multirow{17}{*}{$\begin{array}{c}\text { Basic } \\
\text { information }\end{array}$} & \multirow{2}{*}{ Gender } & Male & & \\
\hline & & Female & 61 & 55 \\
\hline & \multirow{4}{*}{ Age } & $20 \mathrm{~s}$ & 42 & 38 \\
\hline & & $30 \mathrm{~s}$ & 43 & 39 \\
\hline & & $40 \mathrm{~s}$ & 24 & 21 \\
\hline & & $50 \mathrm{~s}$ or more & 2 & 2 \\
\hline & \multirow{3}{*}{ Occupation } & An agricultural worker & 50 & 45 \\
\hline & & Domestic work & 46 & 42 \\
\hline & & Etc. & 15 & 13 \\
\hline & \multirow{4}{*}{ Educational level } & Uneducated & 30 & 27 \\
\hline & & Elementary school(Sasic education) & 81 & 73 \\
\hline & & Junior high school & 0 & 0 \\
\hline & & High school & 0 & 0 \\
\hline & \multirow{2}{*}{ Education contents } & Satisfied & 91 & 82 \\
\hline & & Unsatisfied & 20 & 18 \\
\hline & \multirow{2}{*}{$\begin{array}{l}\text { Vocational training } \\
\text { experience }\end{array}$} & Have & 18 & 16 \\
\hline & & Do not have & 93 & 84 \\
\hline \multirow{14}{*}{$\begin{array}{l}\text { Agricultural } \\
\text { resource allocation } \\
\text { and productivity }\end{array}$} & \multirow{5}{*}{$\begin{array}{l}\text { Current status of } \\
\text { crop cultivation }\end{array}$} & Sugar cane & 42 & 38 \\
\hline & & Cassava & 31 & 28 \\
\hline & & Matoke & 25 & 23 \\
\hline & & Banana & 9 & 8 \\
\hline & & Etc. & 4 & 3 \\
\hline & \multirow{4}{*}{$\begin{array}{l}\text { Type of agriculture } \\
\text { engaged in agriculture }\end{array}$} & Tenant farming & 31 & 28 \\
\hline & & A landed farmer & 60 & 54 \\
\hline & & Cooperative farming & 3 & 2 \\
\hline & & Etc. & 17 & 16 \\
\hline & \multirow{2}{*}{$\begin{array}{l}\text { Current status of domestic } \\
\text { animal husbandry }\end{array}$} & Keep an animal & 13 & 12 \\
\hline & & Have no animals & 98 & 88 \\
\hline & \multirow{3}{*}{$\begin{array}{l}\text { Current status of agricultural } \\
\text { equipment use }\end{array}$} & Agricultural machinery & 0 & 0 \\
\hline & & A cart & 30 & 27 \\
\hline & & I never used it & 81 & 73 \\
\hline \multirow{5}{*}{$\begin{array}{l}\text { Drinking } \\
\text { water }\end{array}$} & \multirow{3}{*}{ Type of drinking water } & Well & 47 & 42 \\
\hline & & Ground water & 53 & 48 \\
\hline & & Etc. & 11 & 10 \\
\hline & Distance to the & Within 30 minutes & 106 & 96 \\
\hline & drinking water source & Within an hour & 5 & 4 \\
\hline \multirow{6}{*}{$\begin{array}{l}\text { Housing and } \\
\text { living } \\
\text { environment }\end{array}$} & \multirow{2}{*}{ Owning a kitchen } & Yes & 26 & 23 \\
\hline & & No & 85 & 77 \\
\hline & \multirow{2}{*}{ Owning a toilet } & Yes & 61 & 55 \\
\hline & & No & 50 & 45 \\
\hline & \multirow{2}{*}{ Facility satisfaction } & Satisfied & 22 & 20 \\
\hline & & Unsatisfied & 89 & 80 \\
\hline \multirow{2}{*}{\multicolumn{2}{|c|}{$\begin{array}{l}\text { Willingness to participate in the construction of } \\
\text { infrastructure in the village }\end{array}$}} & Yes & 97 & 87 \\
\hline & & No & 14 & 13 \\
\hline
\end{tabular}


Table 1. (continued)

\begin{tabular}{|c|c|c|c|c|}
\hline \multicolumn{3}{|c|}{ Classification } & Frequency & Percent(\%) \\
\hline \multirow{3}{*}{$\begin{array}{l}\text { Income and } \\
\text { labor hours }\end{array}$} & \multirow{3}{*}{$\begin{array}{l}\text { Monthly family income } \\
\text { (KRW) }\end{array}$} & Over 100,000 won & 20 & 18 \\
\hline & & Over 50,000 won & 85 & 77 \\
\hline & & Over 30,000 won & 6 & 5 \\
\hline \multirow{10}{*}{$\begin{array}{l}\text { Income and } \\
\text { labor hours }\end{array}$} & \multirow{4}{*}{$\begin{array}{l}\text { Main breadwinner's } \\
\text { job in a family }\end{array}$} & Physical labor & 66 & 59 \\
\hline & & Regular employment & 5 & 4 \\
\hline & & Service industry & 29 & 27 \\
\hline & & Farming industry & 11 & 10 \\
\hline & \multirow{2}{*}{ Income satisfaction } & Satisfied & 23 & 21 \\
\hline & & Unsatisfied & 88 & 79 \\
\hline & \multirow{4}{*}{ Daily work hours } & Within 10 hours & 54 & 50 \\
\hline & & Within 8 hours & 40 & 36 \\
\hline & & Within 6 hours & 11 & 10 \\
\hline & & Within 4 hours & 6 & 5 \\
\hline \multirow{2}{*}{ Debt } & \multirow{2}{*}{ Being in debt } & Yes & 88 & 79 \\
\hline & & No & 23 & 21 \\
\hline \multirow{3}{*}{ Disease } & \multirow{3}{*}{ Kind of disease } & Diarrhea or vomiting & 56 & 50 \\
\hline & & Yellow fever & 33 & 30 \\
\hline & & Etc. & 22 & 20 \\
\hline \multirow{7}{*}{$\begin{array}{l}\text { Willingness } \\
\text { to get a job at a } \\
\text { cooperative farm }\end{array}$} & \multirow{3}{*}{ Willingness } & I'll do It & 70 & 63 \\
\hline & & I'll think about It & 12 & 11 \\
\hline & & I can't & 29 & 27 \\
\hline & \multirow{4}{*}{ Reasons for rejection } & Have no experience of cooperative farming & 37 & 33 \\
\hline & & I don't know what kind of labor is required & 33 & 30 \\
\hline & & I have other works to do & 35 & 33 \\
\hline & & Lack of skills & 6 & 5 \\
\hline \multirow{4}{*}{\multicolumn{2}{|c|}{$\begin{array}{l}\text { Intention to participate in opportunities to } \\
\text { learn agricultural technologies? }\end{array}$}} & I'll do It & 72 & 66 \\
\hline & & I'll think about It & 20 & 18 \\
\hline & & I can’t & 12 & 11 \\
\hline & & Etc. & 7 & 6 \\
\hline \multirow{4}{*}{\multicolumn{2}{|c|}{ Measures to improve agricultural production }} & Supply of quality seeds & 25 & 22 \\
\hline & & Agricultural funding support & 24 & 21 \\
\hline & & Agricultural technology training & 17 & 15 \\
\hline & & Etc. & 45 & 42 \\
\hline \multirow{4}{*}{\multicolumn{2}{|c|}{ Necessary for the development of the community }} & Building a road & 19 & 17 \\
\hline & & Elementary school, a reservoir/waterway & 15 & 13 \\
\hline & & Community space & 17 & 15 \\
\hline & & Etc. & 60 & 55 \\
\hline
\end{tabular}

\section{Basic information}

The surveyed basic information on respondents was as shown in Table 1 , and those in their 20s-40s, relatively young age groups, accounted for the majority (98\%) of the participants of the residents meeting. The share of males and females was similar (45:55), and 47\% of respondents answered their family members were mostly elementary school graduates. Only $16 \%$ answered that they received vocational training before and $16 \%$ were found to be literate and thus be able to participate in vocational 
training and learn technology. Out of the surveyed respondents, $45 \%$ answered that their family members were engaged in the agricultural industry and $42 \%$ answered that they did housework (unemployed), which indicates that agriculture is the main industry in the target and that females engaged in housework also can work at places associated with agriculture.

\section{Allocation and productivity of agricultural resources}

To the question on allocation and productivity of agricultural resources, respondents answered as shown in Table 1. Out of the surveyed respondents, farm owners were found to cultivate crops such as sugar cane (38\%), cassava (28\%) and matoke (23\%) and most of them were found to grow food crops simply by sowing seeds on fields without any special agricultural technology. As the allocation of foods is seriously insufficient, it is necessary to concentrate labor force on cooperative farms to improve food production or transfer agricultural technology that can increase the amount of cultivation through measures such as using agricultural machinery. Compared to the high young population, the number of jobs is relatively low and most of them are jobless. However, they are mostly literate and are highly willing to participate in technical training. The results indicate that the most urgent task in the target area is to transfer to them technology related to its major industry, agriculture, including techniques to repair agricultural machines (Table 1).

The total number of animals bred in Flow Village (total population 69) and Sabati Village (total population 82) on average was as follows: chickens (32 per village), ducks (26 per village) and goats ( 30 per village). The households that owned domestic animals accounted for $12 \%$ of the surveyed respondents. Although chickens, goats and ducks raised as a primary source of food or for living in the village accounted for $42 \%, 25 \%$ and $20 \%$ respectively, the farms that raised the livestock accounted only for $12 \%$, which indicates that those who simply own domestic animals is recognized as a rich family in the villages. In terms of the agricultural equipment used in the villages, most of the respondents were found not to use any equipment other than wagons (27\%), which can be attributed to the fact that most households as a small farm owner rely on minimum-scale agriculture in which farmers sow seeds on an empty space individually not as a cooperative farm.

\section{Drinking water}

To the question on drinking water, respondents answered as shown in Table 1. Drinking water was found to be supplied sufficiently from wells (42\%) and ground water (48\%), and $96 \%$ of the respondents answered that drinking water sources were located within 30 minutes, which indicates that there is no issue in supplying water.

\section{Housing and living environment}

Kitchen and toilet conditions, some of the most useful indicators of living environments, were surveyed, and the results were as shown in Table 1 . About $77 \%$ of the respondents answered that there was no separate kitchen and kitchens in most houses tended to be blended with rooms. Toilets and washrooms were located near houses without any clear boundary. Since sewage was found to be often flown into houses in many cases, it is urgently needed to improve housing conditions. Out of the respondents, $45 \%$ answered that there was no toilet in their houses and even though there were toilets, they tended to use one designated point near their houses as a toilet. In this poor living environment, sewage can flow into houses when it rains. Most houses were made of wooden boards and within a space as small as $3.3 \mathrm{~m}^{2}$, about five family members lived together, which indicates that many residents live in a very poor environment.

\section{Education}

The education completion rate of respondents and conditions for education were surveyed and the results were as shown in Table 1. The primary education completion rate in Uganda tended to be high as primary education in Uganda is compulsory. The primary education completion rate of the villages surveyed in this study was $73 \%$, indicating that most residents in the villages were literate. However, some were unable to receive proper education as they had to do housework or take care of their little siblings. Elementary schools and facilities were old and decrepit and $80 \%$ of 
the respondents answered that they were not satisfied with the facilities. However, $82 \%$ were found to be mostly satisfied with the contents of education. The results show that primary education has been well provided but that it is still necessary to invest in and repair facilities.

\section{Intention to participate in the project of establishing village infrastructure}

Respondents' intention to participate in establishing infrastructure in villages was surveyed and the results were as shown in Table 1. The majority of the respondents (87\%) answered that were willing to participate in establishing infrastructure, and $2-13 \%$ answered that there were willing to do so, but could not because of their poor living circumstances.

\section{Income}

Residents' income level was also surveyed and the results were as shown in Table 1. Out of the surveyed respondents, 79\% answered their income was not sufficient, indicating that the income level required to make a living was not met. Due to the low income, $91 \%$ relied on borrowings and were unable to find other means to earn money. In terms of monthly family income, $77 \%$ were found to earn 50,000 won monthly, far short of the income level required for living. In terms of means to make a living, manual labor accounted for 59\%, indicating that it is difficult to create a certain level of income in this poor structure. To the question about daily working hours, $50 \%$ answered that they worked over 10 hours. Compared to the long working hours, their income is too low and this highlights the importance of improving poor working conditions.

\section{Debt}

The debt of residents was surveyed as shown in Table 1 and $79 \%$ answered that they had debt (excluding buying on credit) in their family. Most respondents did not have a constant means of living and for this reason businesses that can continuously use labor force need to be promoted to address this problem. Their insufficient income for living was found to be covered by debts from lenders or loan sharks in villages.

\section{Disease}

The diseases that residents had were surveyed and the results were as shown in Table 1. Poor health and hygiene conditions such as contaminated drinking water and excrement that was flown into houses resulted in symptoms such as diarrhea and vomiting (over 50\%) and yellow fever symptoms $(30 \%)$. The results can be attributed to poor hygiene conditions and living conditions. Malnutrition and poor living conditions resulted in low-weight or undersized children and they were also found to experience frequent diarrhea and vomiting. These problems can be addressed through projects for improving living environments. To reduce nutritional imbalance, continuous means of living need to be provided for residents by creating jobs and increasing income through community empowerment projects.

\section{Intention to work at cooperative farms}

To the question on the intention to participate in a cooperative farm to be created for increasing the income of village residents, $63 \%$ answered they were willing to participate and $11 \%$ answered that they would think about it (Table 1), indicating that most residents in the surveyed villages preferred the cooperative farm. Those who answered they would not participate (27\%) chose the following reasons. About $33 \%$ answered they had not experienced any cooperative farm before and 30\% answered they did not know about the types of labor required to run the farm. About 33\% answered that they had to do other works at the same time and 5\% answered that they did not have sufficient skills. The results showed that they were still little aware of cooperative farms.

\section{Intention to participate in opportunities to leam agricultural technology}

To the question on the intention to participate in opportunities to learn advanced agricultural technology, $66 \%$ answered that they were willing to participate and $18 \%$ answered that they would think about it (Table 1). A total of $84 \%$ were willing to receive education if opportunities were given, showing a high interest in advanced agricultural technology. 


\section{Measures to improve agricultural production and suggestions}

To the question about measures to improve agricultural production, a main source of income in the surveyed villages, $22 \%$ answered distributing quality seeds and $21 \%$ answered subsidies for farmers (Table 1). Training on agricultural technology was also chosen $(15 \%)$. The results show that if opportunities and funds for increasing agricultural productivity are given, residents are expected to participate in projects for expanding the agricultural industry.

\section{Elements required to develop local communities}

To the question about things required to improve villages and promote community projects, $17 \%$ answered roads connected to markets and $13 \%$ answered close elementary schools, reservoirs and irrigation. Future-oriented community spaces where village residents can gather were also mentioned (15\%). Based on the results, it can be concluded that it is necessary to nurture leaders for villages, provide education on technology, pioneer markets for products and meet residents' needs for infrastructure for living. This is expected to play an important role in empowering villages.

\section{Conclusion}

This study suggested creating tourism farms and empowering rural communities as a measure to improve the quality of life by reducing relative poverty that residents in underdeveloped countries experience, creating jobs and increasing income. Literature review, stakeholder interviews, on-site investigations, focus-group interviews, a residents meeting and a questionnaire survey were performed and the following results were obtained.

First, Uganda has abundant water resources as $17 \%$ of its territory is covered by lakes and rivers and it has the potential to increase agricultural production based on its fertile soil and favorable natural conditions. If agricultural technology can be transferred based on its abundant human resources and low labor costs, it will be possible to produce and process various crops including sugar cane and cassava, connect the existing agricultural industry with other in- dustries through tourism agriculture and improve high-added values, which will improve residents' quality of life and even serve as an opportunity to spread the success of the project to other rural villages across the country.

Second, the candidate land for creating a tourism farm is about 10 minutes away by car from the downtown of the target city and the center of tourism, and thus it is very accessible. The large-sized land is publicly owned and it has good soil and irrigation conditions and gives dynamic landscapes with hills. Water can be smoothly supplied and there are abundant human resources such as young people and females, which makes the land suitable as a candidate land for creating the farm.

Third, local residents were mostly farm owners and they cultivated sugar cane, cassava, matoke, banana and coffee. Due to lack of agricultural technology, their production was low and they were little aware of tourism agriculture. However, once agricultural technology is transferred and communities are vitalized through a cooperative farm, it will be possible to promote high value-added tourism agriculture industries.

Fourth, tourists who visit Jinja enjoy activities such as rafting, fishing, horse riding and strolling along the shoreline of Lake Victoria and near the origin of the Nile River. East African University, a cooperative partner of this project, has its second campus in Jinja and provides specialized education on the regional characteristics of Jinja. As it is selected as an excellent university in Africa, it seems to be suitable to nurture experts as a higher education institution. It is also positively considering to create a regional development department within the university to produce experts, and, if necessary, establish a technical training center for general people, which is expected to contribute to generating synergic effects through the convergence of education, agriculture and tourism.

Fifth, the fertile soil and favorable climate of Jinja combined with advanced agricultural technology to be transferred can improve the productivity of cash crops and the Jinja government expressed its intention to provide institutional support for residents to improve productivity and promote secondary and tertiary industries and even to invest physical resources, if necessary, for the success of this project.

Sixth, problems such as absence of agricultural technol- 
ogy and lack of jobs resulted in inconsistent income sources and poor living environments. Despite the fact, most residents are literate and are able and highly willing to learn technology. Once agricultural technology is transferred and communities are vitalized, residents' income and quality of life will improve and it is essential to implement rural community empowerment projects to do so.

This study aimed to establish measures to vitalize a rural community empowerment project for residents in Jinja, Uganda by creating a tourism agricultural complex, focusing on on-site feasibility investigations. To do so, various methods such as on-site investigation, stakeholder interview and questionnaire survey were adopted to empirically analyze. Once tourism resources in Jinja and other potential resources in its neighboring rural areas are connected, experts will be produced through technological education and local communities for residents will be vitalized. Jobs can be also created for young people and women in Jinja from a long-term perspective and their income can be increased. This is expected to improve their quality of life, spread to other rural villages across the country as a role model and ultimately play a role as a catalyst for reducing the number of poor farmers in the agricultural-driven economy. To promote this project, the Korean government needs to establish a system for community empowerment projects, produce experts through lifelong education and develop programs suitable for regional sentiments. The Ugandan government needs to provide firm support for administrative and institutional policies and local residents also need to have a strong belief that they can do. Korea has transformed itself from a late comer in agricultural technology to a leader by raising farmers' awareness, expanding efficient agricultural infrastructure, commercializing and specializing farming businesses and developing agriculture as a sixth industry beyond primary, secondary and tertiary industries. Korea's experience of successfully achieving economic growth through agricultural development can be a good example for Uganda to promote rural development.

For the sustainable growth of rural community empowerment projects in underdeveloped countries, it will be necessary to continue to research long-term directions and effects of national development and a model for empowering communities by stage.

\section{References}

Choi, H.S. and Y.H. Lee. 2015. The community development effects of the fair travel home stay business: The case of the mountain village 'Betini' in Nepal. J. Crit. Soc. Policy. 49:433-473.

Han, B.S. 2008. Yeongja and Junsu's golden days examination of the activities of the village workers involved in the community development program of the late 1950s. Crit. Stud. Mod. Korean Hist. 12(1):85-137.

Heo, J. and S.H. Hong. 2017. Implementation plan and implications of international development cooperation projects for agriculture in 2017. Naju, Korea: Korea Rural Economic Institute. Retreived from http://reposito ry.krei.re.kr/handle/2018.oak/22263

Ji, E.G. 2006. Community and empowerment. J. Community Welf. 19:47-75.

Jung, H.K., S.S. Lee, S.G. Kang, and S.O. Jeong. 2015. An analysis on the factors affecting the improvement of competence of the strong small farm. J. Agric. Ext. Community Dev. 22(3):261-268. https://doi.org/10.1265 3/jecd.2015.22.3.0261

Jung, J.W. 1997. Agricultural extension, rural adult education and community development. J. Agric. Ext. Community Dev. 4(2):385-392.

Kim, K.H., D.M. Oh, and C.S. Jung. 2017. Learning phase and capacity building in the rural community development: Focusing on the independent rural community creation project. J. Agric. Ext. Community Dev. 24(1):49-61.

Korea International Cooperation Agency and Korea Association of International Development and Cooperation. 2019. A comprehensive report on the local area survey in 2018. KOICA-KAIDEC Public-Private Cooperation Incubation Program(pp. 219-267).

Kwon, J.Y., E.S. Kim, and S.E. Bae. 2015. A study on residents' competency education needs of rural village types: Focused on the building up rural village revitalization. J. Agric. Ext. Community Dev. 22(1):1-14.

Kwon, O.S., K.W. Lee, and E.I. Son. 2008. The trend of regional capacity building programs and a model development. J. Reg. Stud. 16(4):133-156.

Lee, D.B. 2018. A study on the analysis of official development assistance for regional capacity development in developing countries. Master's Degree, Sangmyung University, 
Cheonan, Korea.

Ministry of Agriculture, Food and Rural Affairs. 2014. Handbook of general agricultural and fishery development projects. Sejong, Korea: Author.
Oh, H.E. and Y.G. Kim. 2015. The activation plan of an agricultural region through resident participation: Focusing on Jeongeupsi Naejangsangdong. J. Korean Inst. Landsc. Archit. 43(5):121-131. 